\title{
Efficiency Considerations and Application Limits of Single-Phase Active Power Filter with Converters for Photoenergy Applications
}

\author{
Saša Sladić, ${ }^{1}$ Srdan Skok, ${ }^{1}$ and David Nedeljković ${ }^{2}$ \\ ${ }^{1}$ Faculty of Engineering, University of Rijeka, Vukovarska 58, 51000 Rijeka, Croatia \\ ${ }^{2}$ Faculty of Electrical Engineering, University of Ljubljana, Tržaška 25, 1000 Ljubljana, Slovenia
}

Correspondence should be addressed to David Nedeljković, davidn@fe.uni-lj.si

Received 30 June 2011; Revised 11 August 2011; Accepted 29 August 2011

Academic Editor: Vincenzo Augugliaro

Copyright (C 2011 Saša Sladić et al. This is an open access article distributed under the Creative Commons Attribution License, which permits unrestricted use, distribution, and reproduction in any medium, provided the original work is properly cited.

\begin{abstract}
A new way of connecting PV sources to adaptive voltage active power filter (AV APF) has been compared with classic approach including active power filter (APF). In standard active power filter applications a relatively high DC link voltage (500 V or even more) with a buck converter or lower voltage (approx. $100 \mathrm{~V}$ ) with boost converter can be used. These two converters appear also in adaptive voltage circuit of AV APF, but in this case it is possible to achieve many different connections of DC source. Benefit of this approach is that the same circuit is used for improving switching conditions in APF and for connection of solar cells. It appears that these two functions support each other and a large variety of DC voltages and currents can be connected to AC mains. Experimental results confirm expectations of increased energy transfer from additional DC source to network, especially for DC voltages being lower than DC link voltage.
\end{abstract}

\section{Introduction}

Renewable energy sources have variable output voltages and time-dependent output power. These unpredictable conditions demand flexible, high-efficiency converter [1]. Further demand of such a converter is high quality of delivered power. That means low-power energy sources should operate at near-unity power factor. It follows that additional DC sources can be connected to active power filter (APF). Basically, APF is a current generator which is intended for power factor improvement, but it can be used for connection of renewable energy sources to electric network, as well. Classic active power filter can operate at different levels of DC link (filter capacitor) voltage, which is usually controlled to be constant. The question, which filter capacitor voltage level is the most suitable for APF in sense of current distortion, has no conclusive answer [2]. However, DC link voltage has to be higher than maximal line voltage $(>400 \mathrm{~V})$ in order to ensure proper APF operation. Such approach has been used for decades [3-11]. Consequently, to obtain sufficient voltage for connection of PV source to DC link of classic APF, even in modern solutions, it is necessary to connect large number of solar cells in series [12].
Adaptive voltage approach is quite rare in active power filtering [13, 14], and adaptive voltage active power filter has not been widely investigated in sense of PV source connection [14]. Circuitry for filter capacitor voltage adaptation could additionally provide energy delivery from PV source, thus optimizing use of hardware. With this approach, beside the benefits of adaptive voltage APF (improved line current waveform and reduced APF switching losses), more energy from a renewable DC source could be transferred to the supply network. Generally, single-phase active power filter can be used for that purpose either with buck or boost DC/DC converter. Buck-converter approach enables high efficiency of DC/DC conversion $[4,12]$, but it is not suitable in cases when the DC source has voltage lower than DC link voltage (usually around $500 \mathrm{~V}$ ). Boost converter is suitable for lower voltages (around $100 \mathrm{~V}$, when the DC link voltage is around $500 \mathrm{~V}$ ). Its main drawback is that its efficiency decreases as the step-up ratio increases [7]. In this paper several topologies are introduced and various possibilities of connections of renewable energy sources to active power filter are discussed and compared in sense of their efficiency for different voltage levels. 
TABLE 1: Selection of active switches in single-phase shunt APF.

\begin{tabular}{lcc}
\hline & $v_{S}<0$ & $v_{S}>0$ \\
\hline$S_{1}$ & 1 & 0 \\
$S_{2}$ & 0 & 1 \\
\hline & $i_{\text {Sr }}>i_{S}$ & $i_{\mathrm{Sr}}<i_{S}$ \\
\hline$S_{3}$ & 0 & 1 \\
$S_{4}$ & 1 & 0 \\
\hline
\end{tabular}

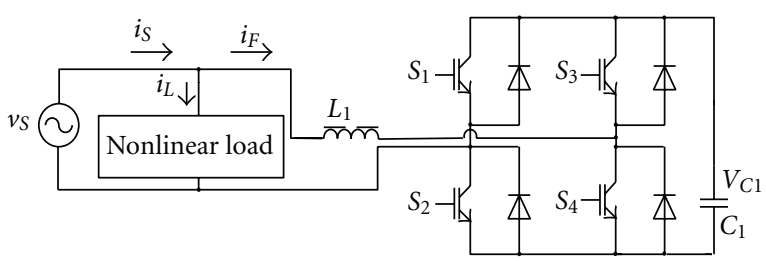

FIGURE 1: Single-phase shunt (H-bridge) active power filter.

\section{Efficiency Consideration of Classic Active Power Filter}

In order to determine APF efficiency, a practical model of APF was used, as shown in Figure 1. Active power filter with constant filter capacitor voltage consists of four switches $\left(S_{1}-S_{4}\right)$. H-bridge acts as a current drain when the neighbouring switches are active, for example, $S_{2}$ and $S_{4}$. On the other hand, H-bridge acts as a current source in case when the diagonal switches are conducting, for example, $S_{2}$ and $S_{3}$. The combination of conducting switches is selected according to the sign of supply network voltage $v_{S}$ and the sign of supply current reference error (i.e., the difference between supply current reference $i_{\text {Sr }}$ and its actual value $i_{S}$ ), as shown in Table 1.

Therefore, always one transistor in a transistor leg is conducting; transistor switching conditions are rather hard, because its switching voltage is determined by DC link voltage $V_{C 1}$. This voltage is quite high $(>320 \mathrm{~V}$, typically $500 \mathrm{~V}$ [2]) for an APF connected to classic $230 \mathrm{~V}, 50 \mathrm{~Hz}$ electric network. That means DC (PV) source voltage has to be high, at least $500 \mathrm{~V}$.

Typical experimental waveforms during APF operation, including DC link voltage, are shown in Figure 2. It can be noted that DC link voltage was about $600 \mathrm{~V}[2,15]$. That means photovoltage of connected solar cells would have to be higher than this DC link voltage, oppositely energy transmission to AC network would not be possible. Consequently, a large number of solar cells have to be connected in series and eventual shadowing of one section of solar array can stop energy transfer of the whole system.

In order to increase capability of energy transfer to AC mains, energy transfer has to be enabled for lower voltages $(<100 \mathrm{~V})$, as well. Tests were conducted with DC voltage of $33 \mathrm{~V}$ (DC source, or one module of solar cells). That means a boost converter, shown in Figure 3, has to be used, or some other step-up converter, possibly with electric transformer [5].

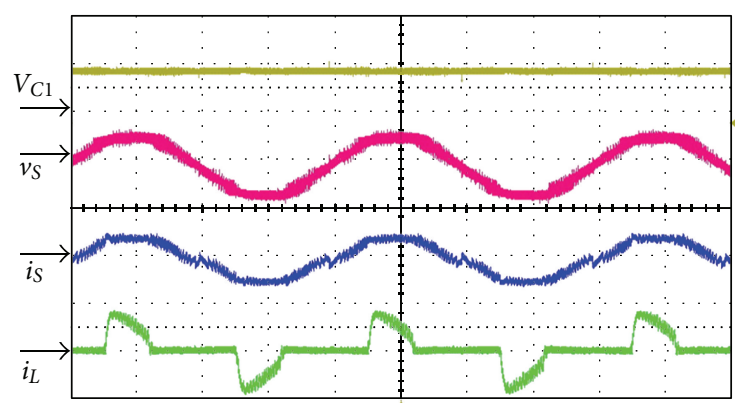

Figure 2: Measured waveforms of active power filter (APF), filter capacitor voltage $\left(V_{C 1}\right)$, line voltage $\left(v_{S}\right)$, line current $\left(i_{S}\right)$, and load current $\left(i_{L}\right) ; \operatorname{THD}\left(i_{S}\right)=7.1 \%, \operatorname{THD}\left(i_{L}\right)=92 \%$, (5 A/div., $500 \mathrm{~V} /$ div., $5 \mathrm{~ms} /$ div.).

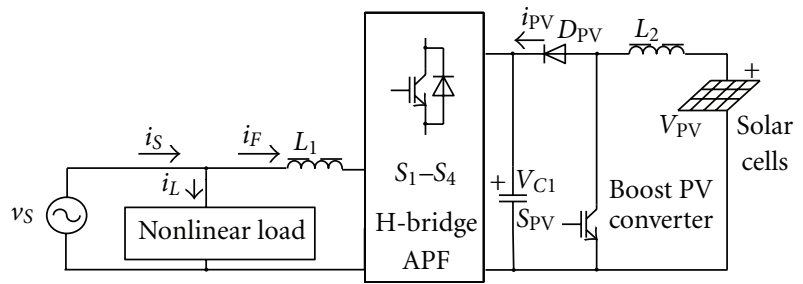

FIGURE 3: Single-phase shunt active power filter with boost converter and PV source [7].

DC source voltage $V_{\mathrm{PV}}$ is quite low compared to DC link voltage $V_{C 1}$, which makes energy transfer demanding [10], so DC link voltage has to be reduced in order to obtain significant energy transfer.

It was noticed that energy transfer from DC source to electric network strongly depends on DC link voltage. In the test, shown in Figure 4, the lowest possible DC link voltage was chosen, and it was recorded that $145 \mathrm{~W}$ was transferred from PV source to AC network. In spite of flexibility of this approach, it can be noted in the literature that buck converter is more frequent [8]. Intention of further work was to increase efficiency of APF system and to enable connection of lower voltages to APF. Furthermore, transmitted power should be increased.

\section{Efficiency Consideration of Adaptive Voltage Active Power Filter}

One possible approach to adaptive voltage active power filter (AV APF) is shown in Figure 5. This topology is obtained in frame of adaptive voltage converter which is used for adaptation of filter capacitor voltage to the conditions in electric network. This approach can be found in inverters $[13,16]$, but it is quite rare in APF applications [14]. It is important to notice that for discharging of filter capacitor a boost converter has been used and a buck converter for its charging. In this case an efficiency improvement can be expected since voltage adaptation improves the switching conditions in active power filter (H-bridge). It is important to mention that for such a result switching frequency of 


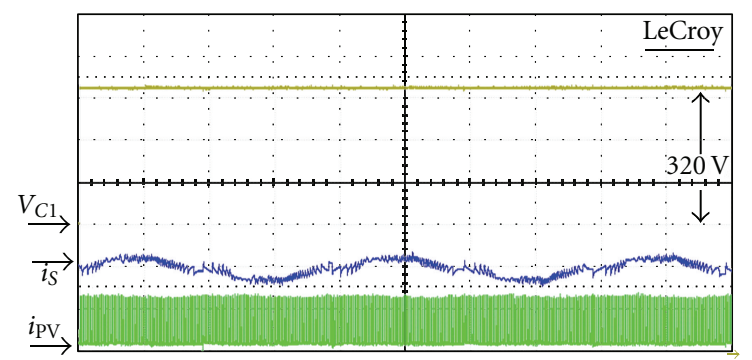

FIGURE 4: Measured filter capacitor voltage $\left(V_{C 1}\right)$, line current $\left(i_{S}\right)$, and boost converter output current $\left(i_{\mathrm{PV}}\right)$ for maximal power $(P=$ $145 \mathrm{~W})$ for given DC source $(33 \mathrm{~V})$ and constant filter-capacitor voltage (100 V/div., $5 \mathrm{~A} /$ div. $)$.

adaptive voltage circuit $\left(S_{5}\right.$ and $\left.S_{6}\right)$ was set to $5 \mathrm{kHz}[14]$ in order to limit the switching losses of adaptive voltage converter, shown in Figure 5.

Adaptive filter capacitor voltage has influence on both harmonic distortion (THD) of line current $\left(i_{S}\right)$ and switching conditions of entire PV system (H-bridge and DC/DC converter). Filter capacitor reference voltage is formed on basis of absolute line voltage. When the APF DC link is being discharged, filter capacitor voltage $\left(V_{C 1}\right)$ demands higher voltage; otherwise filter capacitor voltage has to be close to absolute line voltage. In this way, source current $\left(i_{S}\right)$ ripple is decreased compared to classic approach [14]. Mathematically, filter capacitor reference voltage can be expressed as

$$
\begin{gathered}
v_{C r}=k_{1}\left|v_{S}\right|+k_{2} \cdot \operatorname{sign}\left(\left(i_{F}\right) \cdot\left(-v_{S}\right)\right), \\
v_{C r}=k_{1}\left|v_{S}\right|+k_{2} \cdot i_{f k} .
\end{gathered}
$$

Constant $k_{1}$ has to be slightly higher than 1 , and $k_{2}$ has resistive character. Its value should be around $10 \Omega$ or higher. Current $i_{f k}$ is defined as a current which is supplied from the APF when the APF acts as a current source. This current is continuous, which is different from the current which is supplied from the filter capacitor, which is discontinuous. Experimental results for AV APF are shown in Figure 6. During the intervals within the cycle, when the AV APF is acting as a current source (action of current $i_{f k}$ ), filter capacitor voltage $V_{C 1}$ is higher than $600 \mathrm{~V}$. For other intervals, when AV APF is acting as a current drain, voltage $V_{C 1}$ is reduced to around $200 \mathrm{~V}$. When the filter capacitor voltage is controlled to be constant, as shown in Figure 2, its value has to be constantly high $(600 \mathrm{~V})$ in order to avoid converter saturation.

Since the line voltage is sinusoidal, it crosses zero twice a cycle. When the line voltage is so low, filter capacitor voltage could be much lower than $600 \mathrm{~V}$, for example, $200 \mathrm{~V}$, but compensation of nonlinear load will still be possible. Since permanently high-voltage $V_{C 1}$ means higher voltage stress (hard switching) for all switches in APF, adaptive voltage $V_{C 1}$ leads to improved efficiency in spite of larger number of switches, as it was measured and shown in Figure 7.

It was confirmed that intervals of lower filter capacitor voltages support the energy transfer of photovoltaic energy.
Experimental results were recorded for the power of $80 \mathrm{~W}$ received from PV side of converter, see Figure 8 . This figure illustrates the influence of filter capacitor (DC link) voltage to maximal power received from DC/DC converter (e.g., MPPT converter). A value of $80 \mathrm{~W}$ represents the mean power transmitted to AC side of AV APF. Within this test, adaptive voltage of filter capacitor increases the transmitted power from PV source to the AC network approximately by factor two (at this power level), because minimal output current from DC/DC converter represents less than half of its maximal value. Therefore the same converter (boost) can transmit more power to the AC network for the same PV voltage and equal DC/DC converter duty cycle, by adaptive voltage approach.

Adaptive filter capacitor voltage obtains different waveforms for different nonlinear loads, but AV APF filter capacitor always involves intervals of decreased filter capacitor voltage.

\section{Efficiency Consideration of Buck Converter}

Buck converter from Figure 9 can be used for PV energy injection $[4,8]$ both in APF and AV APF applications because its conversion is highly efficient. However, energy transfer is not possible for the PV cells/module voltage being too low.

Buck converter efficiency depends on its output resistance $R_{e}$. It could be written as

$$
\begin{aligned}
\eta & =\frac{P_{O}}{P_{O}+P_{\text {loss }}}=\frac{V_{O}^{2} / R_{e}}{\left(V_{O}^{2} / R_{e}\right)+I_{L}^{2} \cdot r_{L}} \\
& =\frac{V_{O}^{2} / R_{e}}{\left(V_{O}^{2} / R_{e}\right)+\left[V_{O} / R_{e}\right]^{2} \cdot r_{L}}=\frac{1}{1+\left(r_{L} / R_{e}\right)} .
\end{aligned}
$$

In (2), the only losses in inductor parasitic resistance were taken into account. It can be seen that efficiency $\eta$ of buck converter depends on the ratio of inductor parasitic resistance $\left(r_{L}\right)$ and equivalent resistance $\left(R_{e}\right)$. In the case of variable output voltage, output current tends to flow more through diode $D$ rather than through transistor $T$ (same output current) for the same output power. Since diode $D$ has lower voltage drop than transistor, slightly higher efficiency can be achieved with adaptive filter capacitor voltage, rather than with constant filter capacitor voltage. With adaptive filter capacitor voltage, lower input voltage of buck converter can be used, as well.

From the theorem on maximal power, it follows that maximal power given to the load $\left(R_{e}\right)$ equals the power on parasitic resistance $r_{L}$,

$$
P_{\text {Omax }}=\frac{1}{2} P_{\text {IN }}
$$

Since the same current flows through inductor $L$ and the load, it could be written

$$
r_{L}=R_{e}
$$

From (4) it follows that maximal power appears with efficiency of $50 \%$. 


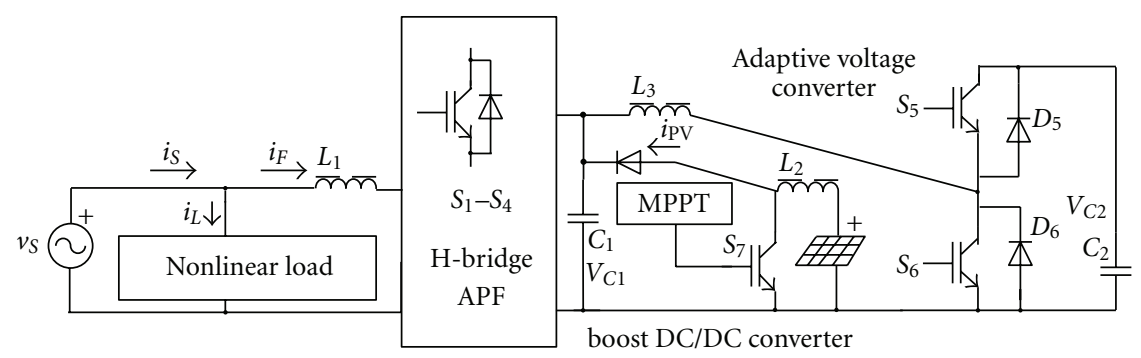

FIGURE 5: Single-phase adaptive voltage active power filter with PV source directly connected to filter capacitor.

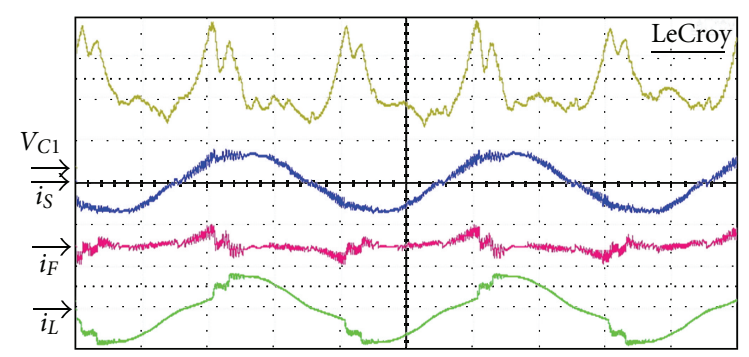

FiguRE 6: Measured waveforms of adaptive voltage active power filter: filter capacitor voltage $\left(V_{C 1}\right)$, line voltage $\left(v_{S}\right)$, line current $\left(i_{S}\right)$, and load current $\left(i_{L}\right) ; \operatorname{THD}\left(i_{S}\right)=4.9 \%, \operatorname{THD}\left(i_{L}\right)=30 \%$, (5 A/div., $200 \mathrm{~V} /$ div., $5 \mathrm{~ms} /$ div.).

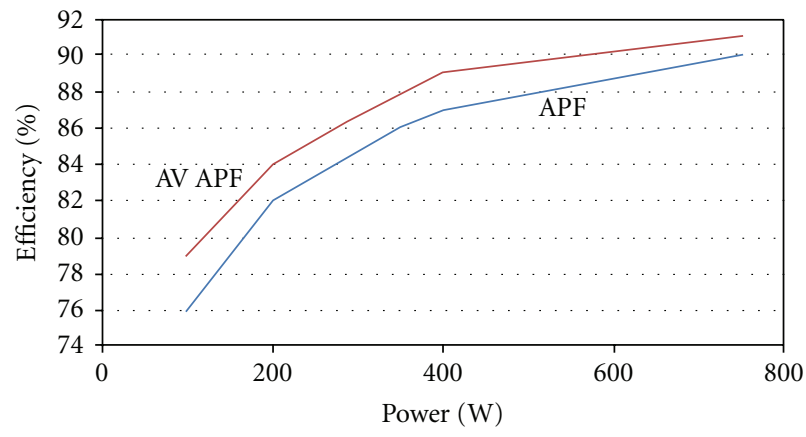

Figure 7: Efficiency of APF compared to AV APF efficiency.

Decreased filter capacitor voltage indicates that equivalent resistance

$$
R_{e}=\frac{V_{C 1}}{i_{\mathrm{PV}}}
$$

decreases, as well. DC/DC converters are usually designed in order to ensure high efficiency, which means $R_{e} \gg r_{L}$. Reduced equivalent output resistance meets condition (3) at higher output current. That means power transmitted to AC network is increased by periodical voltage drop. Efficiency of buck converter (2) is generally high; however, it is desirable that voltage difference between input and output voltage is as low as possible [17], especially for higher switching frequencies. High periodic change of voltage difference between input and output voltage has negative influence on its switching losses; hence for the design of buck converter in

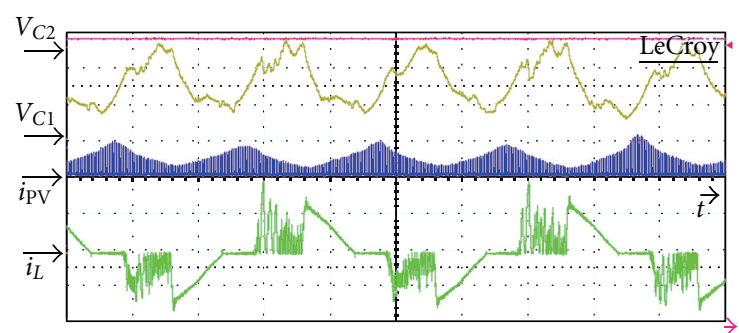

FIGURE 8: Injection of PV current $i_{\mathrm{PV}}$ with adaptive filter-capacitor voltage $V_{C 1}\left(200 \mathrm{~V} /\right.$ div, $P_{\mathrm{PV}}=80 \mathrm{~W}, 5 \mathrm{~A} /$ div, $\left.5 \mathrm{~ms} / \mathrm{div}\right)$.

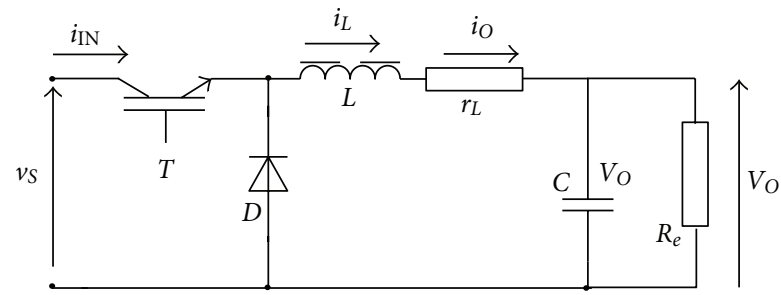

FIGURE 9: Buck converter with its parasitic resistance $r_{L}$.

AV APF application, it is preferable that buck converter has lower switching frequency.

\section{Efficiency Consideration of Boost Converter}

Boost converter, shown in Figure 10, can be used in applications where PV voltage has to be increased. Its efficiency depends not only on ratio between inductor resistance and equivalent resistance, but also on converter duty cycle,

$$
\begin{aligned}
\eta & =\frac{P_{O}}{P_{O}+P_{\text {loss }}}=\frac{V_{O}^{2} / R_{e}}{\left(V_{O}^{2} / R_{e}\right)+I_{L}^{2} \cdot r_{L}} \\
& =\frac{V_{O}^{2} / R_{e}}{V_{O}^{2} / R_{e}+\left[V_{O} /\left(R_{e} \cdot(1-D)\right)\right]^{2} \cdot r_{L}} \\
& =\frac{1}{1+\left(r_{L} /\left(R_{e} \cdot(1-D)^{2}\right)\right)} .
\end{aligned}
$$

Equation (6) indicates strong relation between duty cycle $D$ of transistor T and boost converter efficiency. Obviously, 


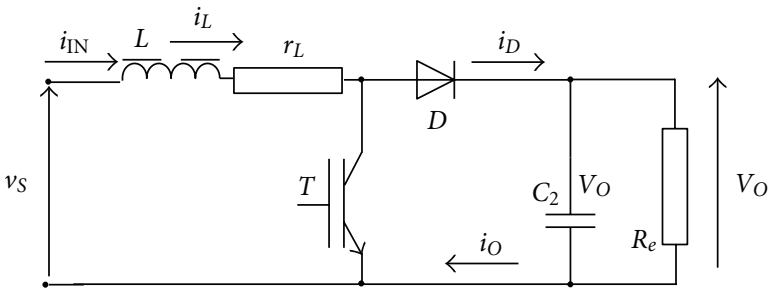

FIGURE 10: Boost converter equivalent circuit.

it is desirable to transfer energy with as low-duty cycle as possible, since input and output voltages are related by

$$
V_{O}=\frac{V_{S}}{1-D}
$$

It means that efficiency will be higher for lower step-up ratio of input $\left(V_{S}\right)$ and output voltages $\left(V_{O}\right)$. In case when the filter capacitor voltage $\left(V_{C 1}\right)$ is lower or equal to the boost converter output voltage, higher efficiency of boost converter can be achieved.

Equivalent resistance $R_{e}$ is defined like in buck converter by (5). It decreases as filter capacitor voltage (periodically) decreases, which means its value is approaching to condition (3). Furthermore, increase of output boost converter current additionally reduces equivalent resistance. Consequently, power transmitted to AC mains is increased by periodical voltage drop. An increase of transmitted power from DC source to AC network means that the same output power will be achieved with lower-duty cycle of DC/DC converter. According to (6), that leads to higher efficiency of boost converter and lower transistor current for the same output power. It can be stated that periodic voltage drop improves the boost converter performance, making it more competitive to buck converter in sense of efficiency since influence of its duty cycle is reduced.

In order to confirm positive effect of filter capacitor voltage adaptation to boost converter, the duty cycle equation (7) for nonideal case can be used

$$
D=\frac{V_{O}-V_{S}}{V_{O}} \cdot \eta
$$

Measurement of boost output current, shown in Figure 8, was repeated for different load levels (duty cycles of boost converter). In one case output resistance was a constant and in other case output resistance was a periodic function. In both cases nonlinear load was successfully compensated by APF. In case of constant filter capacitor voltage, the maximal power was recorded for $D=0.65$. In second case same power was recorded for $D=0.55$. Further increase of duty cycle in second case increases the DC power transfer. So the maximal transferred power is larger in case of AV APF than for classic APF. Measurements were conducted for low DC power level. Measured transferred power was $145 \mathrm{~W}$ for constant filter capacitor voltage and $190 \mathrm{~W}$ for adaptive voltage approach. In both cases the same converter with $33 \mathrm{~V}$ DC source was used.

This simple measurement illustrates the way in which a boost converter increases its low-input voltage power capability, so it can operate with low-duty cycle in order to obtain high efficiency, according to (6). In this way, theoretical expectations are confirmed practically. It can be concluded that variable output voltage of boost converter decreases the transistor current for the same output power and increases the boost converter efficiency.

\section{Two-Direction Buck-Boost (TDB) Converter and Its Application Limits}

Adaptive voltage circuit $[13,16]$ can be used in many ways in order to connect an additional DC source, and some approaches are already reported [18].

Solar cells can be connected to AC network without additional inductor by two-direction boost-buck adaptive voltage active power filter (TDB AV APF) which is shown in Figure 11. This approach has not been discussed in the literature, so far. It consists of classic H-bridge, adaptive voltage circuit and additional transistor, and diode, and DC source. It can be noted that adaptive voltage converter shares the same inductor (with terminal in its middle) with TDB converter. Adaptive voltage converter charges (action of switch $S_{5}$ ) and discharges (action of switch $S_{6}$ ) the filter capacitor $\left(C_{1}\right)$.

Adaptive filter capacitor voltage improves the switching conditions both for $\mathrm{H}$-bridge and for DC/DC converter because of lower switching voltages. Lower voltages mean lower switching losses and higher efficiency. Quasi-resonant approach in APF, especially in single-phase APFs, is quite rare [14]. More sophisticated approach, offering the synergy between recharging of filter capacitor and connection of additional sources, has been proposed in [18]. Application of this circuit could possibly arise in automotive industry, where two or even more different voltage systems coexist (e.g., $12 \mathrm{~V}$ and $42 \mathrm{~V}$ ) and additional energy sources (e.g., solar cells) tend to partially replace energy from fossil fuels.

Inductances $L_{21}$ and $L_{22}$ are the only parts of inductance $L_{2}$. First question, which arises when the inductance should be divided, is ratio of its division. Two main factors influence the final decision for the division ratio of inductance $L_{2}$ : first, PV voltage which (usually) has to be stepped up and second, converter efficiency (which is generally higher for buck comparing to boost converter). However, experiments show that $50: 50$ ratio is most appropriate, because adaptive-voltage converter dynamics demands fast changes and relatively low inductance.

This approach has several advantages compared to solution with constant filter capacitor voltage, since solar cells can release their energy to capacitors $C_{1}$ or $C_{2}$ or to both of them in desired ratio (action of $S_{7}$ selects the interval of energy transfer), according to PV voltage or APF operation needs. It is known that in both converters, boost and buck, load current flows also when an appropriate switch $\left(S_{5}\right.$ or $\left.S_{6}\right)$ is not conducting. This is a consequence of energy accumulated in their inductors. Figure 12 shows equivalent schemes for both cases (boost and buck) for intervals when the $S_{5}$ and $S_{6}$ are not conducting.

Redirecting of flyback current, when the energy is supplied from DC link (can be capacitor either $C_{1}$ or 


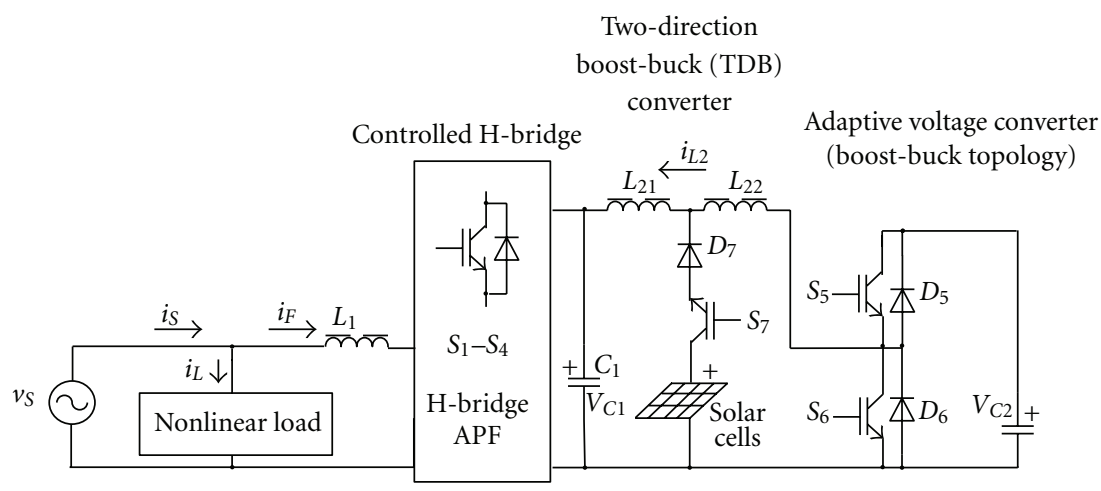

FIGURE 11: Single-phase APF with TDB converter in adaptive voltage circuit (magnetically coupled inductances).

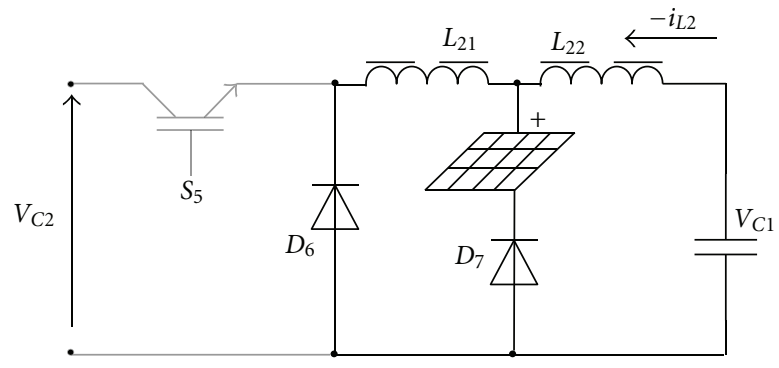

(a)

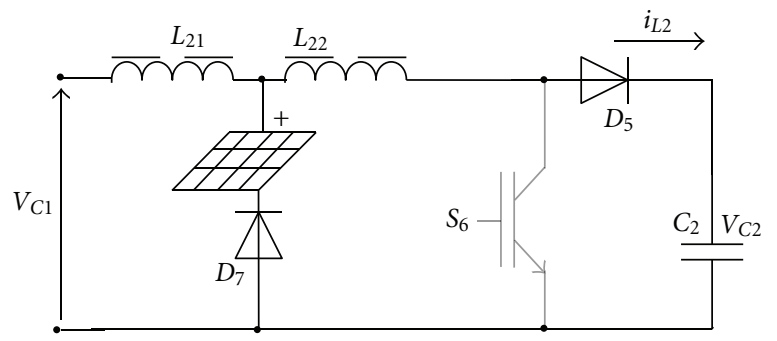

(b)

Figure 12: Buck (a) and boost (b) converters (interval (1-D)T): simplified TDB converter operation.

$C_{2}$ ), means that quasi-resonant circuit (adaptive voltage converter) action supports the current through the solar cells. Current could flow through PV cells even when their voltage is lower than voltages on capacitors $C_{1}$ and $C_{2}$.

In the case of boost converter, current flows through the path: diode $D_{7}$, DC source, inductor $\left(L_{22}\right)$, and in the case of buck converter, current flows through the so-called flyback diode $\left(D_{6}\right)$ or through DC source and diode $D_{7}$. In both cases, current is decreasing. In TDB converter, these currents are commutated to PV source even for very low DC voltages (e.g., $10 \mathrm{~V})$. It is useful to observe mentioned intervals in experimentally recorded waveform of current $i_{L 2}$ (current through inductor $L_{2}$ ), as shown in Figure 13.

Waveforms of filter capacitor voltage $\left(V_{C 1}\right)$, current through inductor $L_{2}\left(i_{\mathrm{L} 2}\right)$ and load current were measured at $110 \mathrm{~V}$ of supply voltage. When the $i_{\mathrm{L} 2}$ is positive, capacitor $C_{1}$ is being charged, and when it is negative, $C_{1}$ is being discharged. Charging of $C_{1}$ is related with the buck action from the capacitor $C_{2}$, and discharging is related with the boost action, when the capacitor $C_{2}$ (DC link) is being charged. Condition for solar cells to retake decreasing current is to have positive voltage (buck operation) and to have positive voltage higher than $V_{C 1}$ (boost operation). Energy between two capacitors $\left(C_{1}\right.$ and $\left.C_{2}\right)$ is circulating even when the AV APF is unplugged $\left(I_{F}=0\right)$, so the solar cell can cover APF losses at low loads.

In spite of its advantages, TDB approach is less suitable for low PV voltages than boost converter approach, because TDB internal boost converter transmits energy to higher

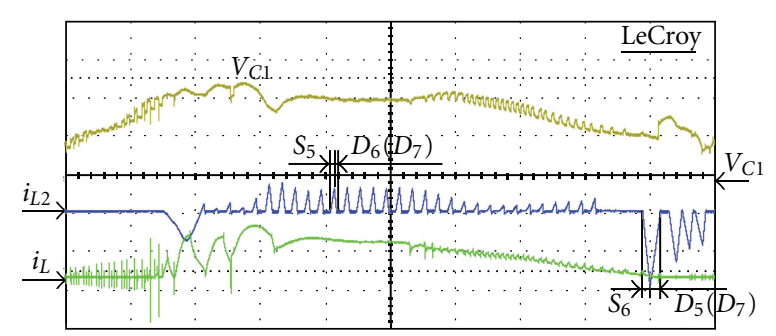

Figure 13: Measured waveforms of filter capacitor voltage $\left(V_{C 1}\right)$, current through $L_{2}\left(i_{L 2}\right)$, and load current $\left(i_{L}\right)$ at $110 \mathrm{~V}$ source voltage and approximately $300 \mathrm{~W}$ load power (100 V/div, $2 \mathrm{~A} / \mathrm{div}$, $1 \mathrm{~ms}$ (div.).

voltage $\left(V_{C 2}\right)$ than the boost converter, connected to adaptive voltage $\left(V_{C 1}\right)$. However, this disadvantage can be partially removed in cases when the filter capacitor voltage obtains values close to zero. Measured waveforms for such a case are given in Figure 14, where PV energy can be transmitted to the filter capacitor even when the PV voltage is extremely low.

Intervals with low filter capacitor voltage, as previously stated, reduce the switching losses in H-bridge. Furthermore, distortion (THD) of line current $\left(i_{S}\right)$ can be also reduced in comparison with constant voltage APF operation, as was previously reported $[14,18]$. It can be stated that TDB connection, as well as direct AV APF connection, increases the energy transfer from secondary DC source. The cause for PV current increase in TDB configuration is a combined action of DC link capacitor and PV source. The percentage 


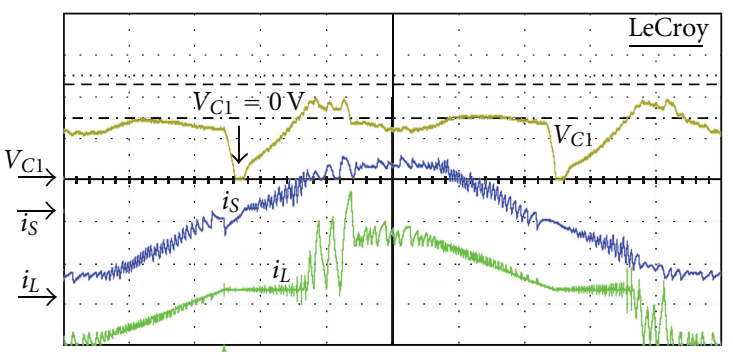

FIGURE 14: AV APF operation and voltage adaptation with multiple nonlinear loads; measured filter-capacitor voltage $\left(V_{C 1}\right)$, source current $\left(i_{S}\right)$, and load current $\left(i_{L}\right)$ at $110 \mathrm{~V}$ source voltage and approximately $300 \mathrm{~W}$ load power ( $100 \mathrm{~V} / \mathrm{div}, 2 \mathrm{~A} / \mathrm{div}, 2 \mathrm{~ms} / \mathrm{div}$.).

TABle 2: Comparison of different APF converter types in sense of switch and inductor number in addition to the possibility of connection of low DC voltages and efficiency.

\begin{tabular}{lcccc}
\hline & $\begin{array}{c}\text { Number of } \\
\text { switches }\end{array}$ & $\begin{array}{c}\text { Inductors } \\
\text { (mass) }\end{array}$ & $\begin{array}{c}\text { PV } \\
\text { voltage }\end{array}$ & Efficiency \\
\hline APF & 4 & 1 & - & + \\
AV APF & 6 & 2 & - & ++ \\
APF + buck & 5 & 2 & - & + \\
APF + boost & 5 & 2 & + & - \\
AV APF + buck & 7 & 3 & $+/-$ & + \\
AV APF + boost & 7 & 3 & ++ & + \\
TDB AV APF & 7 & 2 & + & $+/-$ \\
\hline
\end{tabular}

of this increase depends on filter capacitor voltage and DC source voltage. For $110 \mathrm{~V}$ of supply voltage, intervals appear when filter capacitor voltage reaches zero. In this case any DC voltage could transfer energy to filter capacitor.

At low loads and lower supply voltages, voltage $V_{C 1}$ could reach zero voltage, but with power approaching $1 \mathrm{~kW}$, adaptive voltage tends to the waveform from Figure 8 . In each case, energy from the solar cells could be transferred to AC mains. It can be noted that numerous connections of additional DC sources can be obtained. Some of them are compared in Table 2. Topologies were tested at flexible prototype based on TMS320LF2407.

\section{Conclusion}

Renewable energy sources are usually of uncertain or low voltage, and their connection to AC mains is rather difficult, especially because high efficiency is demanded. To solve this complex problem, active power filter (APF) can be used. However, adaptive voltage active power filter (AV APF) has lower losses because of soft switching. Besides, adaptive voltage converter can be used to support connection of low-voltage DC source. That makes AV APF very attractive for different renewable energy applications. In this paper two emerging connection types were compared in sense of their performances. Both solutions that were analyzed, direct connection of additional DC source to filter capacitor and two-direction boost-buck (TDB) converter, enable application of lower voltages than in case of classic, constant voltage APF. Energy transferred to AC mains is increased compared to the case of APF with constant filter capacitor voltage. Improvement in case of direct connection of boost converter to AV APF is higher than in case of TDB converter (measurements were conducted with $33 \mathrm{~V}$ DC source), but TDB converter has lower number of inductors and can be lighter.

\section{References}

[1] M. Taherbaneh, A. H. Rezaie, H. Ghafoorifard, K. Rahimi, and M. B. Menhaj, "Maximizing output power of a solar panel via combination of sun tracking and maximum power point tracking by fuzzy controllers," International Journal of Photoenergy, vol. 2010, Article ID 312580, 13 pages, 2010.

[2] D. A. Torrey and A. M. A. M. Al-Zamel, "Single-phase active power filters for multiple nonlinear loads," IEEE Transactions on Power Electronics, vol. 10, no. 3, pp. 901-908, 1995.

[3] T. Al Chaer, J.-P. Gaubert, L. Rambault, and M. Najjar, "Linear feedback control of a parallel active harmonic conditioner in power systems," IEEE Transactions on Power Electronics, vol. 24, no. 3, pp. 641-653, 2009.

[4] T. F. Wu, H. S. Nien, C. L. Shen, and T. M. Chen, "A singlephase inverter system for PV power injection and active power filtering with nonlinear inductor consideration," IEEE Transactions on Industry Applications, vol. 41, no. 4, pp. 10751083, 2005.

[5] J. Wang, F. Z. Peng, J. Anderson, A. Joseph, and R. Buffenbarger, "Low cost fuel cell converter system for residential power generation," IEEE Transactions on Power Electronics, vol. 19, no. 5, pp. 1315-1322, 2004.

[6] G. R. Walker and P. C. Sernia, "Cascaded DC-DC converter connection of photovoltaic modules," IEEE Transactions on Power Electronics, vol. 19, no. 4, pp. 1130-1139, 2004.

[7] N. Patcharaprakiti, S. Premrudeepreechacharn, and Y. Sriuthaisiriwong, "Maximum power point tracking using adaptive fuzzy logic control for grid-connected photovoltaic system," Renewable Energy, vol. 30, no. 11, pp. 1771-1788, 2005.

[8] T. F. Wu, H. S. Nien, H. M. Hsieh, and C. L. Shen, "PV power injection and active power filtering with amplitude-clamping and amplitude-scaling algorithms," IEEE Transactions on Industry Applications, vol. 43, no. 3, pp. 731-741, 2007.

[9] S. B. Kjaer, J. K. Pedersen, and F. Blaabjerg, "A review of singlephase grid-connected inverters for photovoltaic modules," IEEE Transactions on Industry Applications, vol. 41, no. 5, pp. 1292-1306, 2005.

[10] D. D. C. Lu and V. G. Agelidis, "Photovoltaic-battery-powered DC bus system for common portable electronic devices," IEEE Transactions on Power Electronics, vol. 24, no. 3, pp. 849-855, 2009.

[11] R. W. Erickson and D. Maksimović, Fundamentals of Power Electronics, Kluwer Academic, Boston, Mass, USA, 2nd edition, 2001.

[12] Y. Chen and K. M. Smedley, "A cost-effective single-stage inverter with maximum power point tracking," IEEE Transactions on Power Electronics, vol. 19, no. 5, pp. 1289-1294, 2004.

[13] D. M. Divan and G. Skibinski, "Zero-switching-loss inverters for high-power applications," IEEE Transactions on Industry Applications, vol. 25, no. 4, pp. 634-643, 1989.

[14] S. Sladić, B. Barišić, and M. Soković, "Cost-effective power converter for thin film solar cell technology and improved 
power quality," Journal of Materials Processing Technology, vol. 201, no. 1-3, pp. 786-790, 2008.

[15] Q. Li and P. Wolfs, "A review of the single phase photovoltaic module integrated converter topologies with three different DC link configurations," IEEE Transactions on Power Electronics, vol. 23, no. 3, pp. 1320-1333, 2008.

[16] S. Behera, S. P. Das, and S. R. Doradla, "Quasi-resonant inverter-fed direct torque controlled induction motor drive," Electric Power Systems Research, vol. 77, no. 8, pp. 946-955, 2007.

[17] M. S. Rahman, Buck converter design issues, M.S. thesis, Linköping Institute of Technology, Linköping, Sweden, 2007, LiTH-ISY-EX-06/3854-SE.

[18] S. Sladić, P. Zajec, and D. Nedeljković, "Transformerless connections of low voltage DC sources to single-phase shunt active power filter with adaptive filter capacitor voltage," in Proceedings of the International Symposium on Power Electronics, Electrical Drives, Automation and Motion (SPEEDAM '10), pp. 1537-1540, Pisa, Italy, June 2010. 


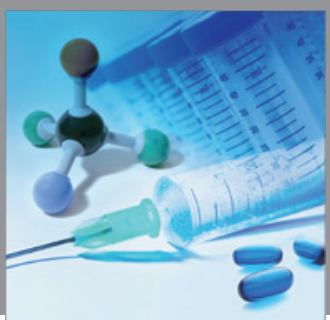

International Journal of

Medicinal Chemistry

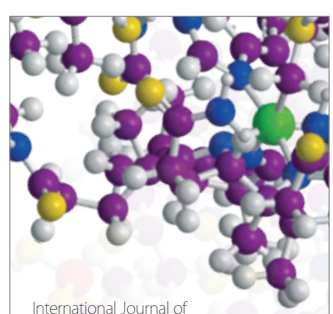

Carbohydrate Chemistry

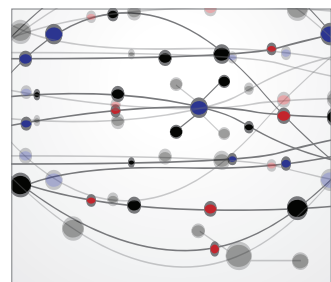

The Scientific World Journal
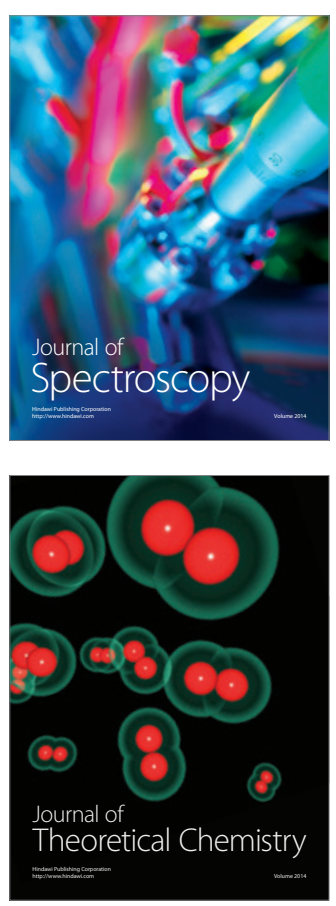
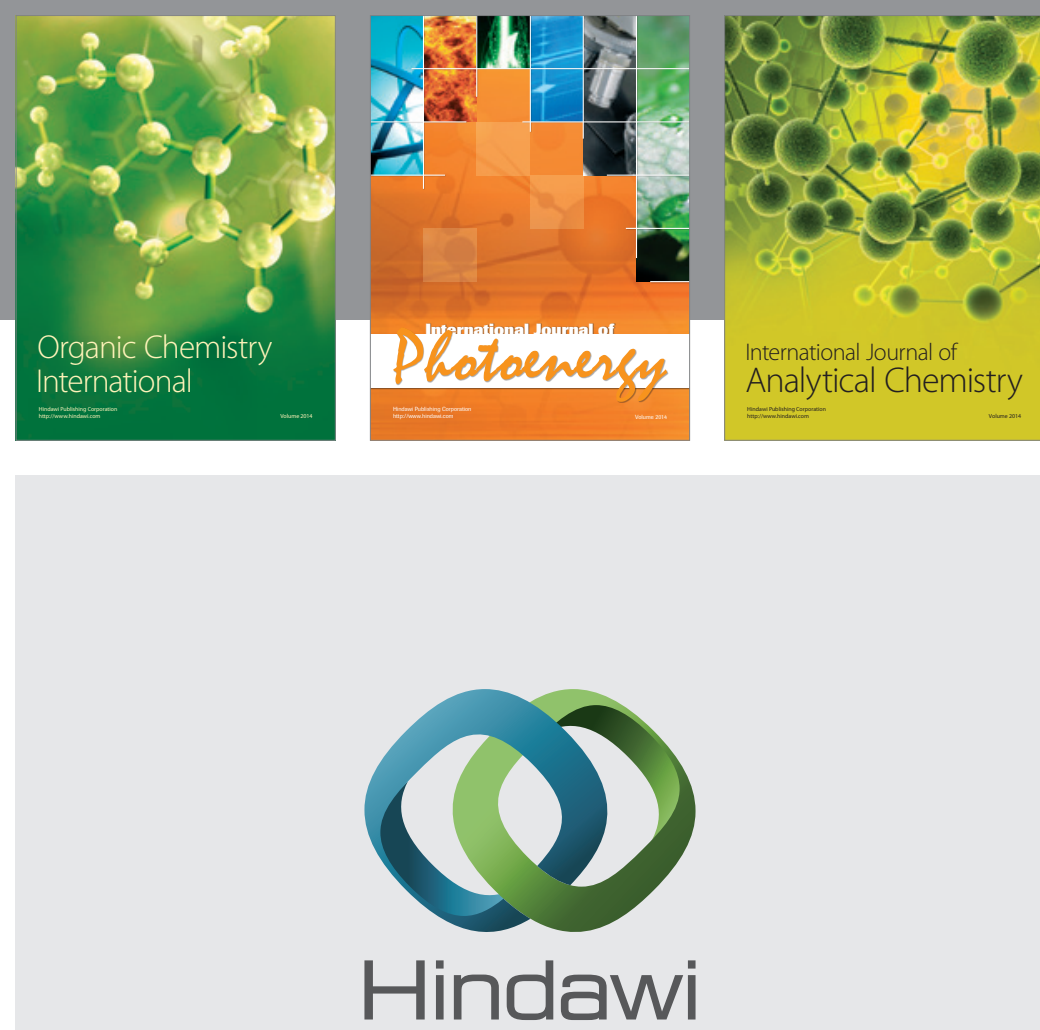

Submit your manuscripts at

http://www.hindawi.com
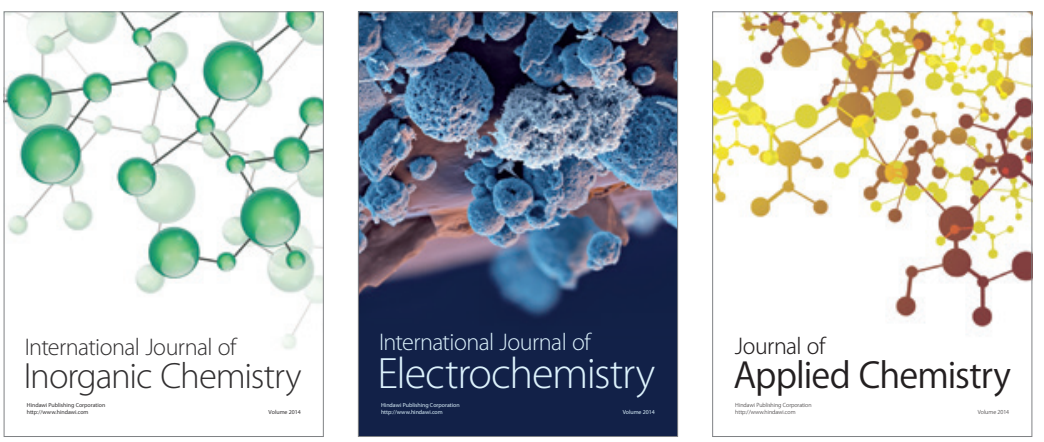

Journal of

Applied Chemistry
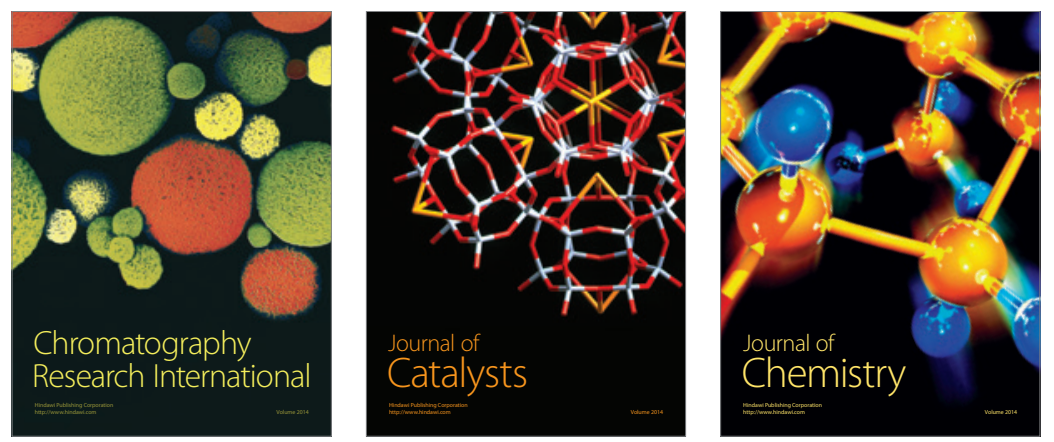
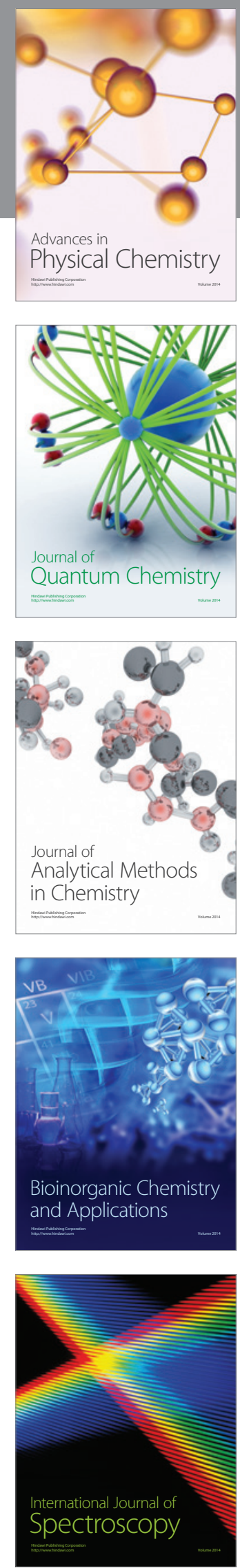